\title{
KAJIAN KEBIJAKAN PENENGGELAMAN KAPAL PELAKU ILLEGAL FISHING DENGAN DISCOURSE NETWORK ANALYSIS
}

\author{
( A STUDY ON SINKING ILLEGAL FISHING VESSELS POLICY WITH DISCOURSE NETWORK \\ ANALYSIS)
}

\author{
Wahyu Hassapni', Robert Kurniawan ${ }^{2}$ \\ Politeknik Statistika STIS ${ }^{1}$ \\ Politeknik Statistika STIS ${ }^{2}$ \\ Jalan Otto Iskandardinata No. 64C, Jakarta Timur 13330 \\ E-mail: wahyuhassapni@gmail.com
}

\begin{abstract}
ABSTRAK
Kebijakan penenggelaman merupakan salah satu langkah langka yang dilakukan oleh Menteri Kelautan dan Perikanan (KKP) untuk mengurangi pencurian ikan di wilayah perairan Indonesia. Kebijakan tersebut memberikan dampak positif diantaranya meningkatkan kesejahteraan nelayan, namun terdapat juga kontra yang muncul terhadap kebijakan ini. Pro dan kontra kebijakan ini dimuat dalam wacana berita online. Untuk menganalisa suatu wacana dibutuhkan suatu metode yang tepat. Pada penelitian ini menggunakan metode baru untuk analisis wacana yang disebut dengan Analisis Jaringan Wacana. Hasil dari penerapan metode tersebut adalah kompleksitas dari suatu wacana dalam bentuk jaringan.
\end{abstract}

Kata kunci: analisis jaringan wacana, menteri kelautan dan perikanan, pencurian ikan

\begin{abstract}
The ship sinking policy is one of the rare steps taken by the Minister of Maritime Affairs and Fisheries (KKP) to reduce illegal fishing in the waters of the Indonesia. This policy has a positive impact, including increasing the welfare of fishermen, but there are also contra that arise in this policy. The pro and con of this policy are contained in online news discourses. To analyze a discourse, an appropriate method is needed. This study uses a new method for discourse analysis called Discourse Network Analysis. The result of applying this method is the complexity of a discourse in the form of a network.
\end{abstract}

Keywords: discourse network analysis, minister of maritime affairs and fisheries, illegal fishing 


\section{PENDAHULUAN}

Indonesia merupakan salah satu negara kepulauan yang memiliki sumber daya ikan (SDI) melimpah. Menurut Menteri Kelautan dan Perikanan Indonesia Susi Pudjiastuti potensi jumlah tangkapan SDI Indonesia mencapai 12,5 juta ton (Kompas, 2018).

Menurut BAPPENAS (2014) salah satu isu pada perikanan adalah masih maraknya kegiatan IUU (Illegal, Unregulated, and Unreported) Fishing. Contoh kegiatan IUU Fishing yang merugikan negara adalah tindakan pencurian ikan. Susi Pudjiastuti mengatakan bahwa pencurian ikan telah merugikan Indonesia lebih dari RP 2000 triliun. Besarnya kerugian menyebabkan kementerian kelautan dan perikanan (KKP) membuat strategi pemberantasan yaitu melaksanakan penenggelaman kapal pelaku illegal fishing di perairan Indonesia.

Adapun dampak positif yang didapat dari kebijakan tersebut antara lain : meningkatnya stok ikan, meningkatnya konsumsi ikan dan meningkatnya kesejahteraan nelayan. Kebijakan ini juga mendapatkan beberapa reaksi penolakan diantaranya : Luhut Binsar Pandjaitan mengatakan "Tidak ada lagi penenggelaman kapal tahun ini, cukuplah itu" dan Jusuf kalla mengatakan "Pandangan pemerintah, cukuplah ini. Ini juga menyangkut hubungan kita dengan negara lain. Ada, enggak usah saya sebut namanya. Ada protes-protes, pendekatan diplomatik, dan macam-macam"

Berbagai bentuk pro dan kontra dari kebijakan penenggelaman kapal dapat dilihat pada berita di media massa. Untuk menganalisa berita dapat dilakukan dengan beberapa metode diantaranya social network analysis (SNA), content analysis (CA), discourse network analysis (DNA) dan sebagainaya.

DNA adalah pendekatan metodologi yang mengkombinasikan analisis wacana dan analaisis jaringan sosial untuk mengidentifikasi sebuah wacana dalam berbagai dokumen sehingga membentuk sebuah jaringan (Leifeld, 2016).

Dalam penelitian ini akan diterapkan metode DNA pada berita terkait kebijakan menteri kelautan dan perikanan mengenai penenggelaman kapal asing yang melakukan illegal fisihing untuk melihat kompleksitas dari wacana kebijakan tersebut. Sehingga dapat diketahui aktor siapa aja yang terkait, hubungan aktor dengan konsep, aktor dengan aktor, antar konsep dan lainnya dari pernyataan terkait kebijakan penenggelaman kapal asing yang dilakukan menteri kelautan dan perikanan.

Adapun tujuan penelitian ini adalah mengeksplorasi data media online(web portal berita) dan memperoleh pola jejaring wacana kebijakan penenggelaman kapal asing yang melakukan illegal fishing di perairan Indonesia.

\section{METODE}

Menurut Leifeld (2016) DNA adalah pendekatan metodologi yang mengkombinasikan analisis wacana dan analisis jaringan sosial untuk mengidentifikasi sebuah wacana dalam berbagai dokumen sehingga membentuk sebuah jaringan. Breindl (2013) mengatakan bahwa DNA mengkombinasikan analisis isi yang berbasis kualitatif yaitu analisis wacana dengan analisis jaringan sosial untuk mengetahui gagasan-gagasan aktor secara relasional dan sistematis.

Pendekatan ini memungkinkan untuk mengidentifikasi secara sistematis suatu struktur wacana dalam berbagai dokumen tekstual seperti artikel koran atau media cetak ataupun transkrip perdebatan di parlemen (Leifeld dan Haunss, 2012).

Beberapa keunggulan dari DNA yaitu:

1. Dapat melihat aktor siapa saja yang terkait pada suatu wacana

2. Dapat melihat hubungan aktor dengan konsep pada suatu wacana

3. Dapat melihat hubungan aktor dengan aktor pada suatu wacana

4. Dapat melihat hubungan suatu konsep dengan konsep lainnya pada suatu wacana

5. Dapat melihat sentiment dari konsep pada suatu wacana

Dalam menunjang penelitian ini, dilakukan studi pustaka ke beberapa penelitian terkait. Penelitian ini menggunakan Kapow Katalyst 9.6.2 dalam pengambilan data berita online, Java DNA versi 2.0 beta 2.2, R-Studio versi 1.1 .453 dan Gephi 0.9.2 untuk pengolahan data dan visualisasi data. Laptop yang digunakan adalah ASUS X550Z dengan processor AMD FX-7600P Radeon R7, RAM 
8 GB, HDD 1 TB dan SSD 250 GB. Selain Java DNA versi 2.0 beta 2.2 dan R-Studio versi 1.1 .453 peneliti juga menggunakan Mysql sebagai tempat penyimpanan data, dan Microsoft Office 2016.

Data untuk analisis diambil dari web portal berita kompas.com, republika.co.id, tempo.co, cnnindonesia.com, antaranews.com, dan detik.com menggunakan Kapow Katalyst dengan total data yang diperoleh sebesar 319 berita online. Metadata tersebut disimpan dalam database mysql. Adapun variabel yang digunakan dalam penelitian ini adalah sumber wacana yang diperoleh (source), judul dari wacana (headline), pembuat wacana (author), waktu lengkap (date), dan isi dari wacana (content).

Peneliti melakukan pre-processing data dengan cara menyeleksi data sesuai dengan batasan penelitian yakni rentang wacana berita dimulai dari 01 Januari 2018 00:00:00 sampai 01 Maret 2018 00:00:00 serta peneliti juga membuang duplikat wacana berita. Dari pre-processing data yang semula berjumlah 319 berita berkurang menjadi 179 berita.

Pada pengolahan dengan aplikasi DNA dilakukan dengan beberapa tahap yakni :

1. Membuat DNA database. Disini peneliti menggunakan Local DNA File.

2. Mengidentifikasikan user dan permissions set. Disini peneliti menggunakan default user yaitu Admin dengan 12 permissions set.

3. Menentukan statement type. Disini peneliti menggunakan default statement type yakni:
a. Person dengan tipe data short text
b. Organization dengan tipe data short text
c. Concept dengan tipe data short text
d. Agreement dengan tipe data Boolean

4. Menambahkan data atau dokumen kedalam DNA database. Dilakukan dengan cara manual (copy and paste)

5. Coding data. Dilakukan dengan membuat DNA statements yang terdiri dari:

a. Person. Orang atau aktor yang berbicara atau membuat pernyataan.

b. Organization. Organsasi yang membuat pernyataan adalah orang yang berafiliasi dengannya.

c. Concept. Representasi abstrak dari topik yang dibahas, misalnya konsep untuk kebijakan penenggelaman kapal seperti "undang-undang penenggelaman kapal tidak akan merugikan negara".

d. Agreement. Menunjukkan apakah aktor setuju dengan konsep atau tidak. Jika pembicara berbicara tentang konsep dengan cara positif diasumsikan setuju dan sebaliknya dia tidak setuju ketika membuat pernyataan dengan nada negatif.

6. Export data yang sudah di coding

Pada penelitian ini menggunakan eksplorasi data. Data yang sudah diperoleh dari hasil crawling di eksplorasi untuk mendapatkan informasi mengenai kebijakan penenggelaman kapal pelaku illegal fishing di perairan Indonesia. Serta output yang dihasilkan berupa jejaring wacana, dimana output tersebut di interpretasikan.

\section{HASIL DAN PEMBAHASAN}

Kebijakan penenggelaman kapal yang dilakukan oleh menteri kelautan dan perikanan Indonesia Susi Pudjiastuti sudah berlangsung sejak tahun 2014. Selama kebijakan tersebut berlangsung belum ada pro dan kontra dari berbagai kalangan. Namun pada akhir 2017 hingga menjelang Februari 2018 kebijakan itu menjadi perbincangan diberbagai kalangan. Hal ini dikarenakan adanya kontra dari kalangan pemerintah yang menganggap bahwa kebijakan itu harus dihentikan. 


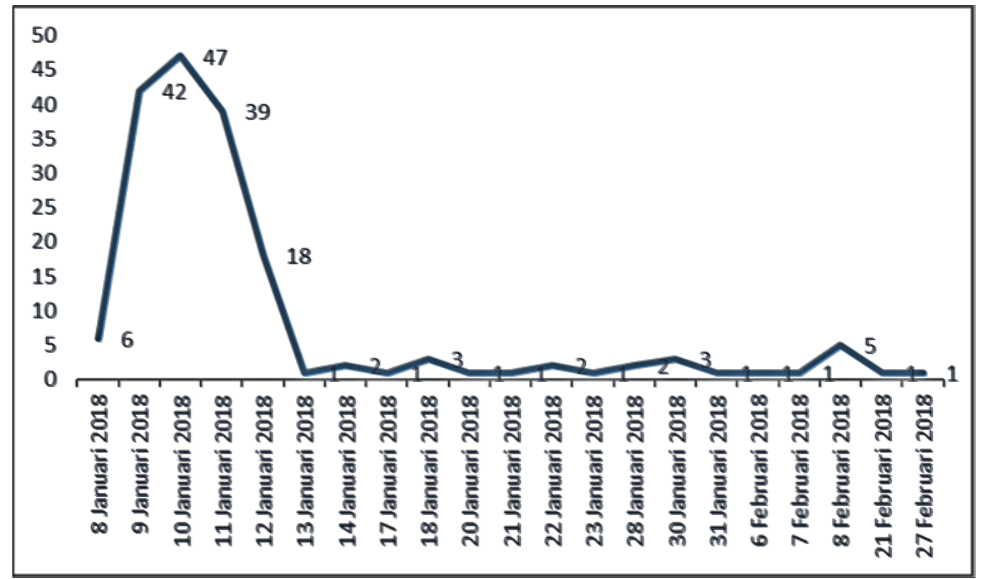

Gambar 1 Pergerakan total berita terkait kebijakan

Gambar 1 menjelaskan mengenai jumlah berita terkait dengan kebijakan penenggelaman kapal pelaku illegal fishing di perairan Indonesia. Pada 8 Januari 2018 berita mengenai kebijakan tersebut mulai diperbincangkan hingga pada puncaknya tanggal 10 Januari 2018, dikarenakan adanya kontra yang disampaikan oleh Luhut Binsar Pandjaitan untuk menghentikan kebijakan itu. Kontra itu juga di dukung oleh statementnya Jusuf Kalla yang menilai bahwa kebijakan tersebut menyebabkan hubungan diplomatik terganggu. Hal ini menyebabkan kebijakan itu menjadi perbincangan. Pada tanggal 12 Januari 2018 jumlah berita terkait kebijakan itu mulai menurun dikarenakan adanya aktor Joko Widodo dan Susi Pudjiastuti yang memberikan statement bersifat positif terhadap kebijakan tersebut. Hingga akhir Februari 2018 jumlah berita itu tidak ada peningkatan secara drastis.

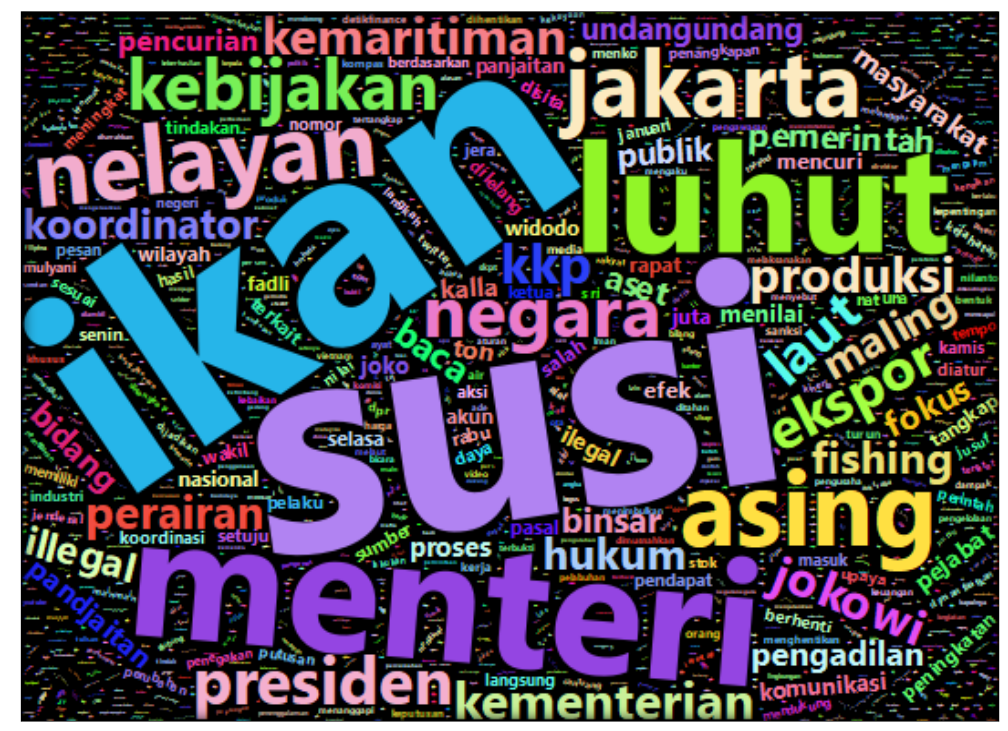

Gambar 2. Plot distribusi kata seluruh berita

Wordcloud di atas menununjukkan kata apa saja yang paling sering keluar di dalam wacana kebijakan penenggelaman kapal pelaku illegal fishing di perairan Indonesia. Distribusi kata hanya berfokus pada kata "susi", "ikan", dan "luhut" karena untuk kata penenggelaman kapal merupakan keyword utama sehingga kata "penenggelaman", "kapal" akan menempati posisi teratas. Disini terlihat bahwa dari ke media kompas.com, republika.co.id, tempo.co, detik.com, antaranews.com, dan cnnindonesia.com kata terkait "susi", "ikan", dan "luhut" frekuensinya cukup besar.

Pertama, kata "susi" ada sebanyak 1115 kata. Ada beberapa hal yang menyebabkan kata "susi" sering disebut yakni susi adalah menteri kelautan dan perikanan Indonesia. Susi sendirilah yang melakukan dan menegakkan aksi penenggelaman kapal pelaku illegal fishing di perairan Indoneisa. Tindakan yang dilakukan oleh susi mendapatkan banyak apresiasi baik di dalam negeri maupun di luar negeri namun, tidak sedikit yang berpandangan negatif tentang apa yang dilakukan 
susi. Hal ini lah yang memicu pro dan kontra dalam kebijakan tersebut. Sehingga banyak berita yang memuat mengenai susi dengan kebijakannya.

Kedua, kata "ikan" ada sebanyak 1057 kata. Kata "ikan" lebih mengarah kepada pencurian ikan. Pencurian ikan di Indonesia sudah bisa dikatakan sering terjadi. Hal itu karena luasnya perairan Indonesia dengan sumber ikannya yang banyak serta minimnya fasilitas untuk mengawasi seluruh wilayah perariran Indonesia.

Ketiga, kata "luhut" ada sebanyak 636 kata. Kata menteri lebih mengarah kepadat Luhut. Luhut Binsar Pandjaitan adalah Menteri Koordiantor Kemaritiman Indonesia yang kontra dengan kebijakan tersebut. Luhut meminta agar memberhentikan kebijakan itu dan meminta kepada Susi agar mempertimbangkan dahulu sebelum ditenggelamkan.

Pada berita terkait kebijakan penenggelaman kapal terdapat beberapa statement. Statement itu dapat dikelompokan menjadi beberapa konsep yang dibuat oleh peneliti. Konsep tersebut dibuat menjadi 4 konsep pro dan 4 konsep kontra.

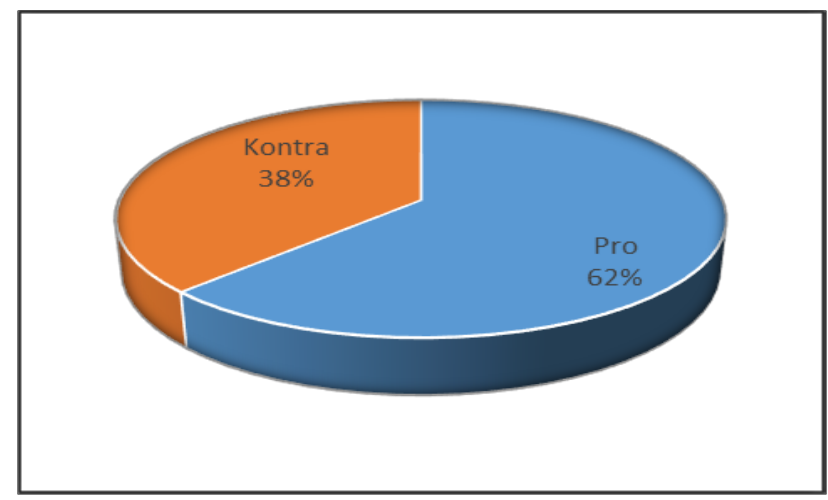

Gambar 3. Distribusi statement terhadap pro dan kontra

Gambar 3 menjelaskan distribusi dari statement yang ada pada berita terhadap kontra dan pro. Jumlah statement yang berkaitan dengan pro sebesar $62 \%$ dan berkaitan dengan kontra sebesar $38 \%$.

Adapun konsep kontra dan pro yang dibentuk oleh peneliti adalah sebagai berikut:

A. Konsep Pro

1. Kebijakan penenggelaman kapal menunjukkan kedaulatan RI

2. Kebijakan penenggelaman kapal memberikan efek jera

3. Kebijakan penenggelaman kapal berakitab meningkatnya sumber daya laut dan kemakmuran nelayan

4. Kebijakan penenggelaman kapal menyebabkan oengurangan kasus pencurian ikan

B. Konsep Kontra

1. Kebijakan penenggelaman kapal tidaklah efektif

2. Kebijakan penenggelaman kapal memperburuk hubungan diplomatik Indonesia

3. Kebijakan penenggelaman kapal menimbulkan permasalahan lingkungan

4. Kebijakan penenggelaman kapal melanggar nilai nilai kemanusiaan dan HAM

Setiap konsep memiliki beberapa statement setuju dan tidak setuju terhadap konsep yang ada, berikut distribusi statement setuju atau tidak setuju yang disajikan dalam barplot.

Selanjutnya peneliti juga menggambarkan bagaimana distribusi statement terhadap organisasi pemerintah dan non pemerintah. Organisasi pemerintah tersebut antara lain : presiden Republik Indonesia, menteri kelautan dan perikanan Indonesia, menteri koordinator kemaritiman, dan lainnya, sedangkan organisasi non pemerintahan antara lain: nelayan, masyrakat, ulama, dan lainnya. 


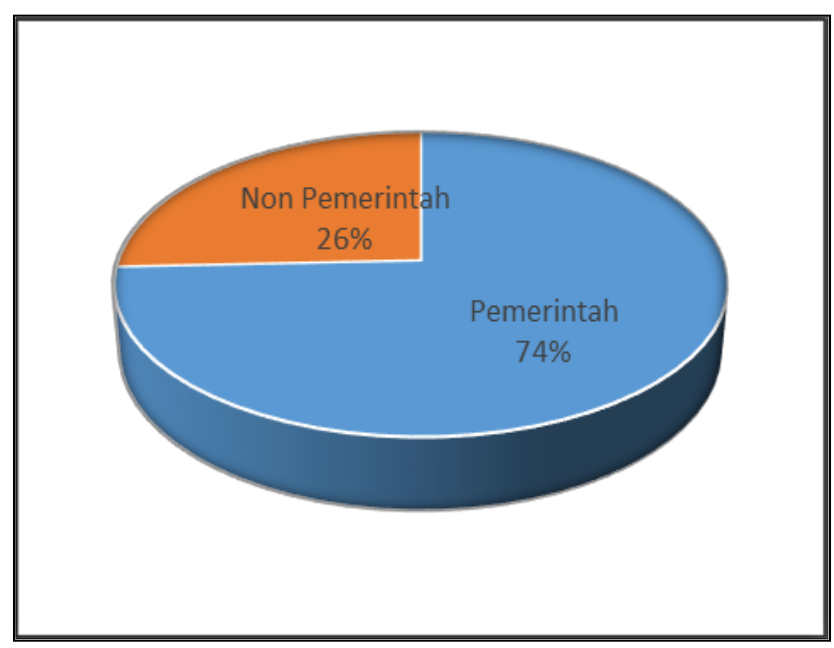

Gambar 4. Distribusi terhadap organisasi

Gambar 4 menunjukkan persentase jumlah statement yang dikemukakan oleh organisasi pemerintah sebesar $74 \%$, sedangkan non pemerintah sebesar $26 \%$. Hal ini menunjukkan bahwa statement yang ada kebanyakan berasal dari pemerintah sendiri.

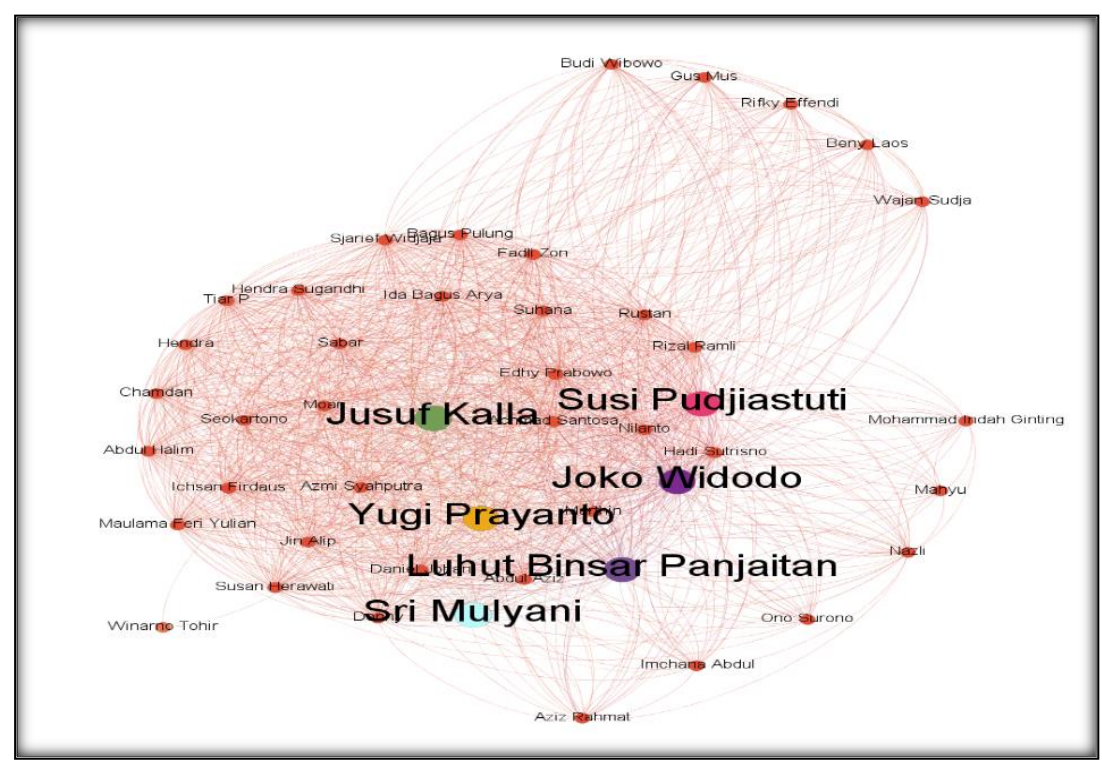

Gambar 5. Person network

Gambar 5 menununjukkan jaringan kongruensi person/aktor yang terkait dalam wacana tersebut. Setiap simpul mewakili aktornya (mis. Jusuf Kalla, Susi Pudjiastuti, etc). Ukuran node sebanding dengan jumlah statement yang muncul di wacana. Warna node tidak berpengaruh. Terlihat bahwa Jusuf Kalla, Joko Widodo, Susi Pudjiastuti dan Luhut Binsar Panjaitan sering muncul pada wacana kebijakan tersebut. Jusuf Kalla memiliki hubungan dengan Luhut Binsar Panjaitan dan Susi Pudjiastuti, dimana dengan Luhut Binsar Panjaitan terlihat kuat. Sedangkan Susi Pudjiastuti memiliki hubungan dengan Luhut Binsar Panjaitan, Jusuf Kalla, dan Joko Widodo, namun terlihat lebih sering disandingkan dengan Joko Widodo. 


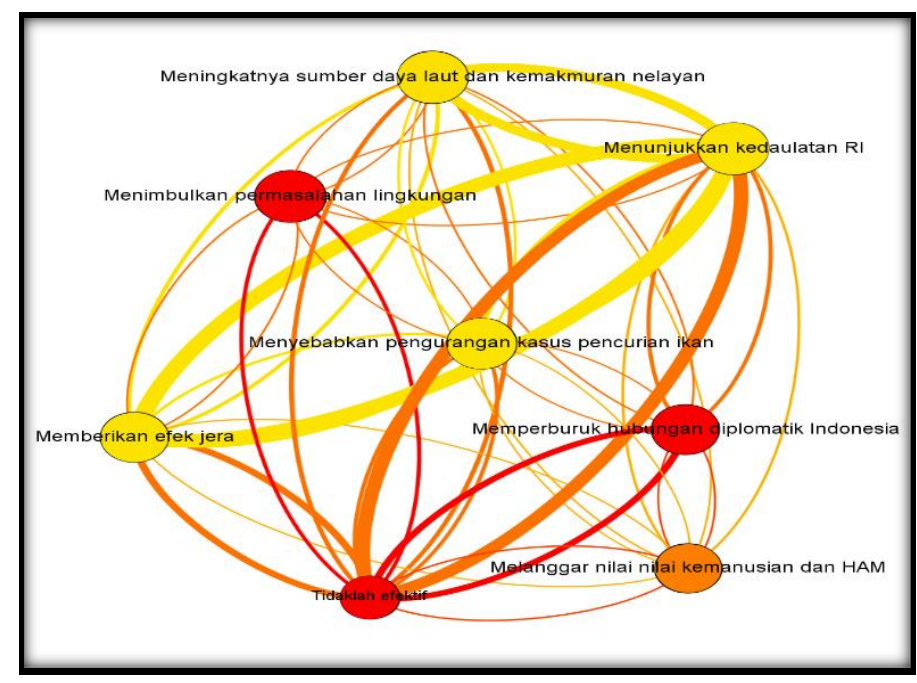

Gambar 6. Concept networks

Gambar 6 menununjukkan jaringan kongruensi konsep yang terkait dalam wacana tersebut. Setiap simpul mewakili konsep yang ada (Kebijakan penenggelaman kapal tidakklah efektif, dan lainnya). Ukuran garis sebanding dengan jumlah statement yang muncul di wacana. Warna node tidak berpengaruh. Terlihat bahwa ada 4 konsep yang sering muncul dalam wacana itu yakni Kebijakan penenggelaman kapal menunjukkan kedaulatan RI, kebijakan penenenggelaman kapal berakibat meningkatnya sumber daya laut dan kemakmuran nelayan, kebijakan penenggelaman kapal tidaklah efektif, dan kebijakan penenggelaman kapal memberikan efek jera.

Untuk kebijakan penenggelaman kapal menunjukkan kedaultan RI sering muncul dikarenakan adanya statement dari Presiden RI yaitu jokowi yang mengatakan bahwa penenggelaman itu adalah law emporcement. Hal ini juga didukung oleh penelitian yang dilakukan Rahman (2015) dan Asley (2018) yang mengatakan bahwa pencurian ikan merupakan tindak pidana di Indonesia, dan penenggelaman kapal merupakan upaya penegakan hukum yang sudah tercantum

dalam Undang-Undang Nomor 45 Tahun 2009. Sehingga terlihat jelas bahwa kebijakan penenggeleman kapal merupakan bentuk dari kedaulatan negara.

Untuk kebijakan penenggelaman kapal berakibat meningkatnya sumber daya laut dan kemakmuran nelayan sering muncul karena salah satu sisi positif yang dirasakan adalah meningkatnya sumber daya ikan dan nelayan lebih leluasa untuk melaut. Hal ini juga didukung oleh penelitian Sompotan (2018) yang mengatakan bahwa illegal fishing di wilayah perairan Indonesia menyebabkan penurunan hasil tangkapan nelayan dan daerah penangkapan yang semakin meluas ke laut lepas, hal ini menyebabkan nelayan tradisional tertinggal. Adanya kebijakan penenggelaman kapal membuat berkurangnya kapal pelaku illegal fishing yang membuat nelayan tradisional tidak perlu melaut ke laut lepas.

Untuk kebijakan penenggelaman kapal tidaklah efektif sering muncul dikarenakan adanya statement dari Luhut Binsar Pandjaitan bahwa stop kebijakan itu, hal ini tentunya menuai kontra yang luar biasa. Serta untuk kebijakan penenggelaman kapal memberikan efek jera sering muncul dikarenakan adanya statement positif dari nelayan, presiden RI dan juga Kementerian Kelautan dan Perikanan yang mengatakan bahwa kebijakan ini akan memberikan efek ketakutan kepada pelaku illegal fishing. Hal ini juga didukung oleh penelitan Istanto (2015) yang mengatakan bahwa upaya penegakan hukum di perairan dan laut yang berkelanjutan membuat efek jera bagi pelaku illegal fishing karena perlengkapan kapal pelaku illegal fishing kebanyakan alat modern dan harganya mahal. Kapal yang digunakan merupakan kapal modern yang canggih. Kapal dan perlengkapan alat yangdigunakan merupakan asset mahal yang dimiliki oleh pelaku, jika hal tersebut ditenggelamkan maka akan membuat para pelaku untuk berfikir seribu kali untuk mengurangi pencurian ikan di wilayah perairan Indonesia karena motif pencurian adalah mencari keuntungan bukan mencari kerugian. 


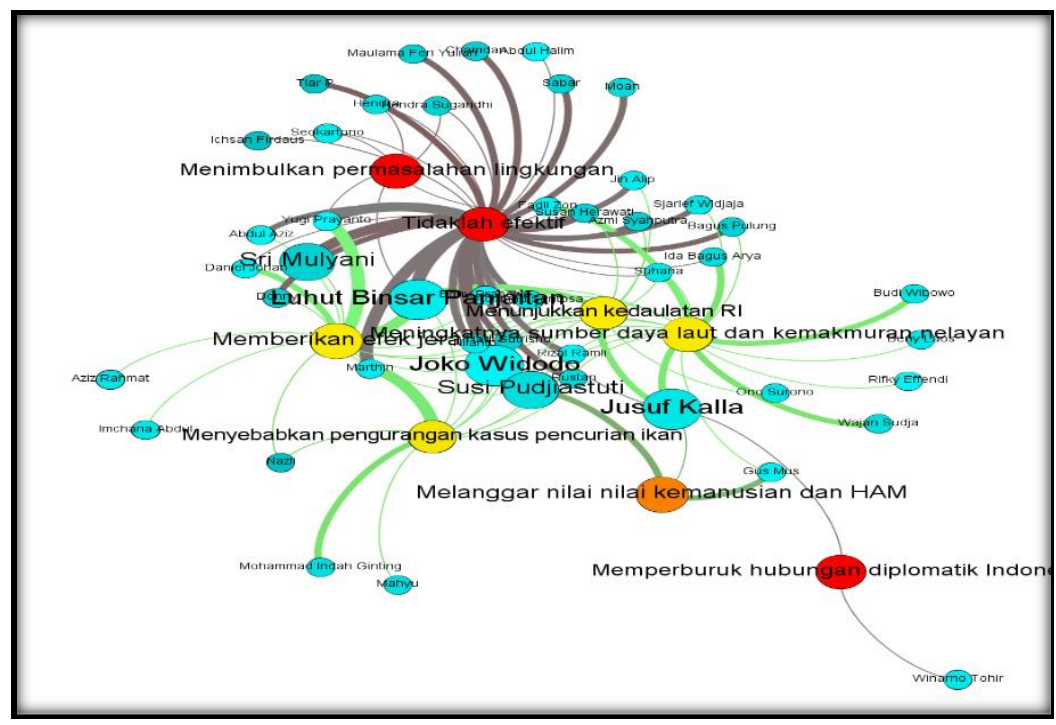

Gambar 7. Person by concept

Gambar 7 menununjukkan jaringan afiliasi antara aktor dengan konsep yang terkait dalam wacana tersebut. Setiap simpul mewakili konsep dan aktor yang ada (mis. Kebijakan penenggelaman kapal tidakklah efektif, Susi pudjiastuti etc). Ukuran node sebanding dengan jumlah statement yang muncul di wacana. Node warna merah menandakan konsep kontra, warna kuning menandakan konsep pro dan warna biru menandakan organisasi. Terlihat bahwa untuk konsep penenggelaman kapal tidaklah efektif banyak di pakai oleh berbagai aktor seperti Susi Pudjiastuti, Luhut Binsar Panjaitan, etc dan ada beberpa konsep juga terkait degan konsep penenggelaman kapal tidaklah efektif.

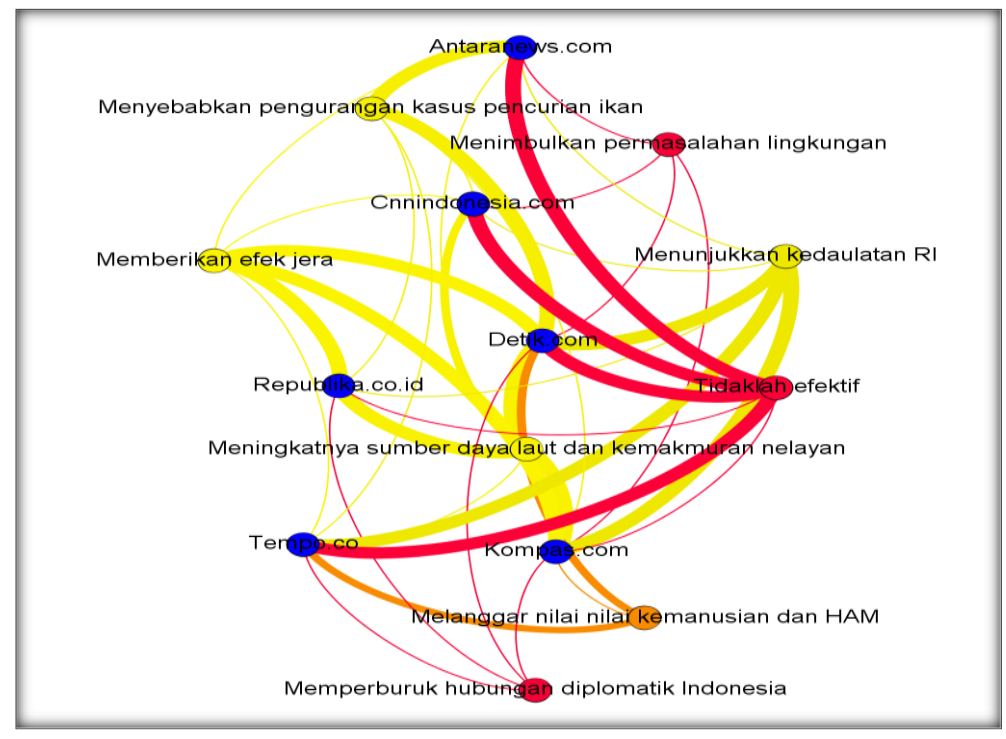

Gambar 8. Concept by source

Gambar 8 menununjukkan jaringan afiliasi antara source/sumber berita dengan konsep yang terkait dalam wacana tersebut. Setiap simpul mewakili konsep dan sumber berita yang ada (mis. Kebijakan penenggelaman kapal tidakklah efektif, cnnindonesia.com etc). Ukuran node sebanding dengan jumlah statement yang muncul di wacana. Node warna merah menandakan konsep kontra, warna kuning menandakan konsep pro dan warna putih menandakan sumber berita. Terlihat bahwa terlihat bahwa kompas.com dan republika.co.id cenderung mempubikasikan wacana berita yang bersifat pro terhadapa kebijakan penenggelaman kapal. Untuk cnnindonesia.com, antaranews.com. tempo.co dan detik. com lebih bersifat netral dalam mempublikasikan wacana berita terkait kebijakan penenggelaman kapal. 


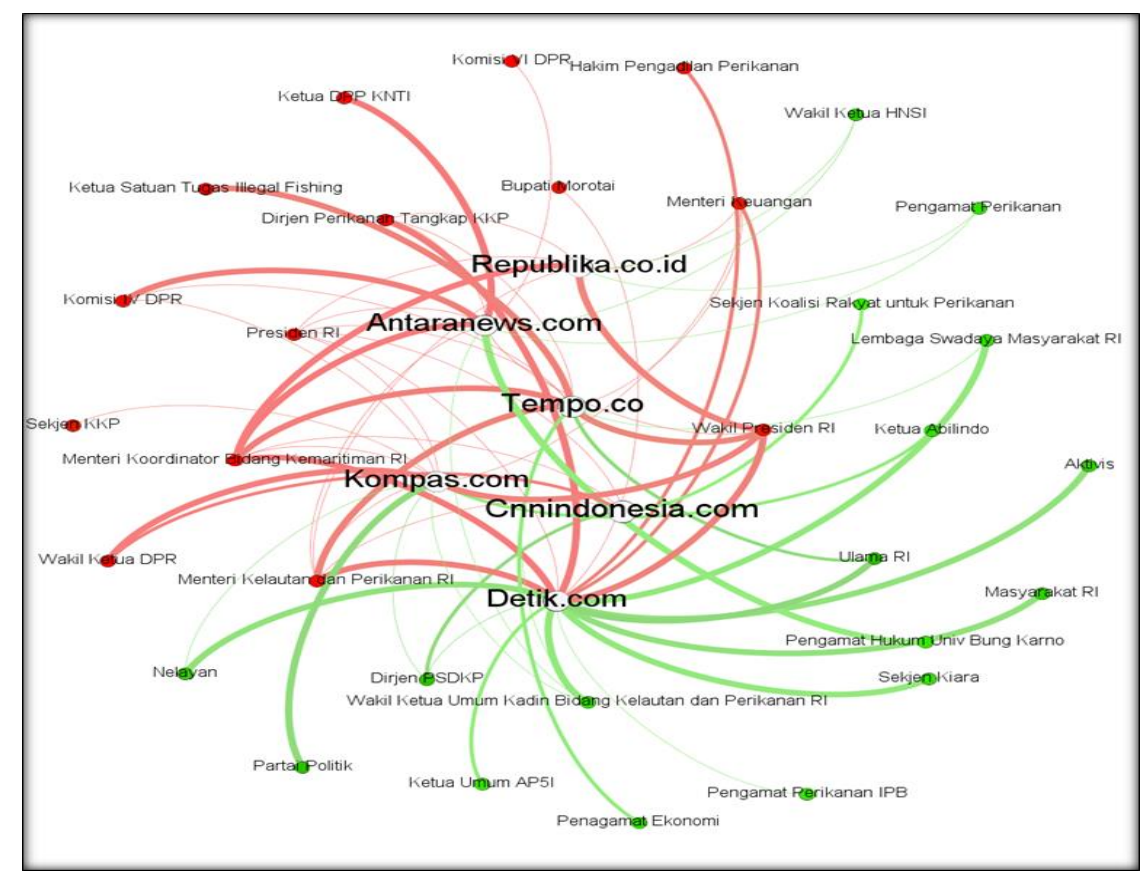

Gambar 9. Organization by source

Gambar 9 menununjukkan jaringan afiliasi antara source/sumber berita dengan organisasi yang terkait dalam wacana tersebut. Setiap simpul mewakili organisasi dan sumber berita yang ada (mis. Presiden, menteri kelautan dan perikanan, cnnindonesia.com etc). Ukuran node sebanding dengan jumlah statement yang muncul di wacana. Node warna merah menandakan organisasi pemerintah, warna hijau menandakan organisasi non pemerintah dan warna putih menandakan sumber berita. Terlihat bahwa kompas.com, tempo.co, antaranews.com, dan republika.co.id lebih memuat organisasi pemerintah kepada berita terkait kebijakan penenggelaman kapal yang dibuatnya. Hal ini bisa diasumsikan bahwa ke empat media tersebut cenderung memihak kepada organisasi kepemerintahan. Sedangkan untuk media cnnindonesia.com dan detik.com lebih bersifat netral dikarenakan node yang mengarah kepada dua media itu terlihat sebanding.

\section{KESIMPULAN}

Dengan pemaparan di atas, dapat disimpulkan bahwa:

1. Berita tekait penenggelaman kapal paling banyak termuat pada awal Januari 2018 yakni pada tanggal 8 sampai 12 Januari di ke enam sumber berita. Dimana masing masing berita memuat kata "ikan", "susi", dan "luhut". Adapaun konsep kontra yang terkandung pada berita ada $38 \%$ dan pro sebesar $62 \%$. Adapun persentase organsasi yang terkait dalam berita terkait adalah non pemerintah sebesar $26 \%$ dan pemerintah $74 \%$.

2. Media terkait seperti kompas.com dan republika.co.id cenderung mempubikasikan wacana berita yang bersifat pro terhadapa kebijakan penenggelaman kapal. Untuk cnnindonesia.com, antaranews.com. tempo.co dan detik.com lebih bersifat netral dalam mempublikasikan wacana berita terkait kebijakan penenggelaman kapal. Media kompas.com, tempo.co, antaranews.com, dan repubila.co.id lebih memuat organisasi pemerintah kepada berita terkait kebijakan penenggelaman kapal yang dibuatnya. Sedangkan untuk media cnnindonesia.com dan detik.com lebih bersifat netral dikarenakan node yang mengarah kepada dua media itu terlihat sebanding. 


\section{DAFTAR PUSTAKA}

Alamsyah, Purnama dan Ikbal Maulana. (2018). Melacak Kompelsitas Wacana dengan Discourse Network Analysis. Jakarta

Arifin, Pupung. 2013. Perssaingan Tujuh Portal Berita Online Indonesia berdasarkan Analisis Uses dan Grafications. Jurnal Ilmu Komunikasi. Vol 10 No 2. 195-212

Asley, Jessie. (2018). Tinjauan Yuridis terhadap Kebijakan Penenggelaman Kapal Asing Illegal Fishing di Indonesia oleh Kementerian Kelautan dan Perikanan dalam Perspektif Hukum Nasional dan Internasional [SKRIPSI]. Universitas Sumatera Utara : Fakultas Hukum.

Bayu, Dimas Jarot. 2019. Menteri Susi Klaim Stok Ikan Melimpah karena Penenggelaman Kapal Asing. Diperoleh dari https://katadata.co.id/berita/2019/02/12/menteri-susiklaim-stok-ikan-melimpah-karena-penenggelaman-kapal-asing. Diakses pada 21.22 PM 17/07/2019.

BAPPENAS. (2014). Kajian Strategi Pengelolaan Perikanan Berkelanjutan. Jakarta: Kementerian PPN/BAPPENAS-Direktorat Kelautan dan Perikanan

Breindl, Yana. (2013). Discourse networks on state-mandated access blocking in France and Germany. Vol 14 No 6. 42-62

Hartik, Andi. (2018). Menteri Susi: Stok ikan Indonesia Naik Jadi 12,5 Juta Ton. Diperoleh dari https://regional.kompas.com/read/2018/08/14/18581041/menteri-susi-stok-ikanindonesia-naik-jadi-125-juta-ton. Diakses pada 09.20 PM 22/04/2019Agresti, A. (2000). Categorical Data Analysis ( $2^{\text {nd }}$ ed). New York: John Wiley \& Sons.

Istanto, Yusuf. (2015). Penenggelaman Kapal Pelaku Illegal Fishing sebagai Upaya Penegakan Hukum Perikanan di Indonesia (Studi Putusan Nomor 4/PID-SUS-PRK/2014/PN TPG Pengadilan Negeri Tanjung Pinang. UNISBANK

Leifeld, Philip, Dana R. Fisher dan Yoko Iwaki. 2013. Mapping the Ideological Networks of American Climate politics. Springer Science.

Leifeld, Philip. (2016). Discourse Network Analysis: Policy Debates as Dynamic Networks. Oxford Handbooks Online.

Rahman, Rofi Aulia. (2015). Penenggelaman Kapal Asing dalam Upaya Perlindungan Sumber Daya Laut di Indonesia: Perspektif Hukum Indonesia dan Hukum Internasional. Yogyakarta: Laboratorium Ilmu Hukum.

Siagin, Tiodora Hadumaon dan Robert Kurniawan. (2018). Kajian Wacana Program Normalisasi Sungai dalam Peanggulangan Bencana Banjir di DKI Jakarta dengan Discourse Network Analysis. Jakarta

Yun, Sun Jin, et al. (2012). A Comparative Analysis of South Korean Newspaper Coverage on Climate Change: Focusing on Conservative, Ptogressive, and Economic Newspappers. Development and Society. Vol 41 No 2. 201-228. 